\title{
Partitioning of assimilated nitrogen in beech (Fagus sylvatica)
}

\author{
F. Martin and M. Ben Driss Amraoui \\ Laboratoire de Microbiologie Forestière, INRA, Centre de Recherches Forestières de Nancy, \\ Champenoux, 54280 Seichamps, France
}

\section{Introduction}

The transport and incorporation of nitrogen in trees involve many complex processes. Nitrogen ions taken up by the root and its symbiotic associates may be retained in root cells for the synthesis of organic compounds or may be translocated directly to the aerial parts. The types of compounds transported, the channels selected for transport and the characteristics of the transport mechanisms, themselves are dependent upon the nitrogen sources available, the characteristics of the plant species, its stage of growth and the environment in which it is grown.

Nitrogen assimilation and translocation have been extensively studied in orchard trees including apple (Hill-Cottingham and Lloyd-Jones, 1977; Tromp and Ovaa, 1979) and Citrus (Kato, 1980). Data are also available on conifers (Martin et al., 1981a; Scheromm et al., 1988) but, so far, no detailed information exists dealing with hardwood species. This investigation examines the importance of the roots in the nitrogen economy of beech (Fagus sylvatica L.) plants, describing labeling studies with $\left[15 \mathrm{~N}^{-} \mathrm{NH}_{4}^{+}\right.$in roots and patterns of transport, accumulation and utilization of assimilated nitrogen.

\section{Materials and Methods}

\section{Growth and labeling of plants}

Seeds of beech ( $F$. sylvatica L.) were germinated in the dark on peat moistened with water at $20^{\circ} \mathrm{C}$ and $98 \%$ relative humidity. After 3 wk, uniform seedlings were transferred to a modified Ever's solution containing $1 \mathrm{mM} \mathrm{NH} \mathrm{NH}_{4}^{+}$in sand culture in a naturally lighted glasshouse. Labeling studies were performed on $100 \mathrm{~d}$ old plants. $5 \mathrm{~d}$ prior to the $15 \mathrm{~N}$-labeling experiment, the plants were transferred to a culture holder consisting of a polystyrene sheet punched with holes to accept the roots. The cultures were placed in aerated, fresh modified Evers's solution and returned to the glasshouse. At the start of an $15 \mathrm{~N}$-labeling experiment, the pump was stopped, the container rapidly drained and refilled with culture solution containing $\left[{ }^{15} \mathrm{~N} \mathrm{NH}_{4}^{+}\left(50 \%{ }^{15} \mathrm{~N}\right.\right.$ atom excess). Two cultures (4 plants each) were harvested at regular intervals over a $4 \mathrm{~d}$ uptake period. The tissues of one culture were divided into roots, stem and leaves, blotted, weighed, and frozen immediately. After being lyophilized, samples were weighed separately and then combined prior to grinding. Xylem exudate was collected from the 
2nd culture, using a Scholander chamber, and frozen for later analysis. Plants were rinsed with distilled water, weighed and frozen.

\section{Analyses}

Soluble and insoluble nitrogen compounds were extracted in a methanol-water mixture as described by Martin et al. (1981b). Amino acid contents in the xylem exudate and tissues were determined according to the method of Genetet et al. (1984). Ammonium in xylem exudates, tissues and digests was measured colorimetrically (Martin et al., 1981b). The \% $15 \mathrm{~N}$ in soluble and insoluble compounds, and xylem exudates was measured by emission spectrometry after diffusion of ammonia from the digest (Martin et al., 1981b).

\section{Results}

\section{Distribution of $15 \mathrm{~N}$ in plant organs}

At the end of the first day of $[15 \mathrm{~N}] \mathrm{NH}_{4}^{+}$ feeding, $73 \%$ of the absorbed $\mathrm{N}$ remained in the root tissues (data not shown). The corresponding value on day 4 was $55 \%$, indicating a low translocation rate of assimilated $\mathrm{N}$ to the shoots. On day 4 , $35 \%$ of the total absorbed $N$ had been incorporated into insoluble root $\mathrm{N}$.

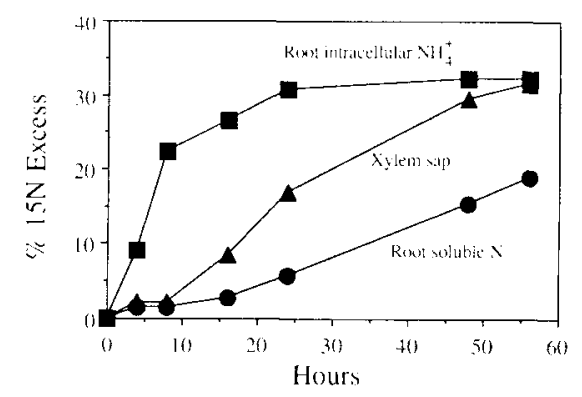

Fig. 1. Time course of ${ }^{15} \mathrm{~N}$ enrichment of root intracellular $\mathrm{NH}_{4}^{+}$and soluble $\mathrm{N}$, and xylem sap $\mathrm{N}$ in 3 mo old Fagus sylvatica L. Labeling of soluble compounds in roots
and xylem sap

Fig. 1 shows the pattern of ${ }^{15} \mathrm{~N}$ labeling of intracellular $\mathrm{NH}_{4}^{+}$, soluble $\mathrm{N}$ in root tissues and xylem sap $\mathrm{N}$. There are some indications that multiple $\mathrm{NH}_{4}^{+}$pools are present in the root. Thus, the labeling of ammonia appears to become saturated at around $30 \% 15 \mathrm{~N}$ abundance (vs $50 \% 15 \mathrm{~N}$ abundance of extracellular $\mathrm{NH}_{4}^{++}$, indicating that 'storage pools' of this ion exist in the roots. Absorbed ammonium- $\mathrm{N}$ was rapidly assimilated into amides and amino acids in root cells. Glutamine, glutamate and asparagine were the most highly labeled components over the time course of the experiment (Table 1). Bleeding sap was collected from the stems of decapitated plants after the addition of ${ }^{15} \mathrm{~N}$ label. The major nitrogenous constituents of the xylem sap of $\mathrm{NH}_{4}^{+}$-grown beech plants were arginine and asparagine, with very little ammonia being transported. These amino acids accounted for $80 \%$ of the $\mathrm{N}$ of root xylem sap and more than half of its nitrogenous solutes on a molar basis. The amino acid level of the xylem sap averaged $19 \mu \mathrm{mol} / \mathrm{ml}$. Feeding beech roots with $\left[{ }^{15} \mathrm{~N}\right] \mathrm{NH}_{4}^{+}$resulted in a simultaneous labeling of xylem-borne amino acids and root soluble $\mathrm{N}$. Xylem translocation of assimilated $15 \mathrm{~N}$ occurred during the first

Table I. Incorporation of $15 \mathrm{~N}$ into root free amino acids.

\begin{tabular}{lcc}
\hline Nitrogen compounds & $\% 15 \mathrm{~N}$ \\
\hline Glutamine & amino-N & 18 \\
& amide- & 20 \\
Asparagine & amino-N & 10 \\
& amide- & 17 \\
Glutamate & & 18 \\
Alanine & 9 \\
$\mathrm{NH}_{4}^{+}$ & 14 \\
Total & 100 \\
\hline
\end{tabular}


hours of exposure, with the isotope abundance gradually increasing to $30 \%$. The isotope abundance of sap amino $\mathrm{N}$ was higher compared to that of amino $\mathrm{N}$ in the root. This suggests that amino acids translocated to shoots were not mixed with the large root amino acid pool. Thus, translocation of products of $15 \mathrm{~N}$ assimilation occurred within a few hours in spite of a large source of potentially available root $14 \mathrm{~N}$-amino acids for translocation.

\section{Discussion}

It has been confirmed by many investigations using an $15 \mathrm{~N}$ tracer method or by direct analysis of xylem sap that asparagine and arginine are the major forms of nitrogen translocated from assimilating roots to sink organs, such as young leaves and buds in trees (Hill-Cottingham and Lloyd-Jones, 1977; Tromp and Ovaa, 1979). The results presented here are also consistent with the view that asparagine and arginine are the primary source materials in the translocation flux of nitrogenous compounds to shoots in beech. The percentages of assimilated $15 \mathrm{~N}$ in amino acids in the xylem sap were considerably higher than in the roots. This suggests the existence of a least two compartmented pools of amino $\mathrm{N}$ in the roots. The lower pool has a rapid turnover rate and is dedicated to translocation, whereas the other is a larger pool with a relatively low turnover rate. The 'translocation pool' is closely connected to the stream of currently assimilated nitrogen. Early products of $\mathrm{NH}_{4}^{+}$ assimilation (e.g., asparagine, glutamine, etc.) remaining in the root cells may subsequently undergo: 1) incorporation into other amino acids for root protein syn- thesis and 2) storage in the vacuole. The physical basis of the compartmentation has not been elucidated. At the tissue level, it is unlikely that the $\mathrm{N}$ assimilation product partitioning can be described among all cell types as a uniform 3-way branched pathway to accumulation, translocation and incorporation. We envisage that, depending upon on the location of a cell within the root, its early $\mathrm{N}$ assimilation metabolites may be more or less available for translocation to shoots than for root maintenance.

\section{References}

Genetet I., Martin F. \& Stewart G. (1984) Nitrogen assimilation in mycorrhizas. Ammonium assimilation in the $\mathrm{N}$-starved ectomycorrhizal fungus Cenococcum graniforme. Plant Physiol. 76, 395-399

Hill-Cottingham D.G. \& Lloyd-Jones C.P. (1977) translocation of nitrogenous compounds in plants. In: Nitrogen Assimilation of Plants. (Hewitt E.J. \& Cutting C.V., eds.), Academic Press, London, pp. 397-406

Kato T. (1980) Nitrogen assimilation in Citrus trees. 1. Ammonium and nitrate assimilation by intact roots, leaves and fruits. Physiol. Plant. $48,416-420$

Martin F., Chemardin M. \& Gadal P. (1981a) Nitrate assimilation and nitrogen circulation in Austrian pine. Physiol. Plant. 53, 105-110

Martin F., Chemardin M. \& Gadal P. (1981b) Détermination isotopique du $15 \mathrm{~N}$ par spectrométrie d'émission dans les tissus végétaux. Physiol. Vég. 19, 513-521

Scheromm P., Plassard C. \& Salsac L. (1988) Nitrogen nutrition of non-mycorrhized maritime pine (Pinus pinaster) grown on nitrate or ammonium. Plant Physiol. Biochem. 26, 261-269

Tromp J. \& Ovaa J.C. (1979) Uptake and distribution of nitrogen in young apple trees after application of nitrate or ammonium, with special reference to asparagine and arginine. Physiol. Plant. 45, 23-28 